\title{
Polymers as Carriers of Gentamicin in Traumatology and Orthopedic Surgery - Current State Of Knowledge
}

\author{
${ }^{1}$ University Clinical Hospital in Wroclaw, Wroclaw Medical University, Wrocław, Poland \\ ${ }^{2}$ Department of Traumatology, Clinic of Traumatology and Hand Surgery, Wroclaw Medical University, Wrocław, Poland
}

A - research concept and design; $\mathbf{B}$ - collection and/or assembly of data; $\mathbf{C}$ - data analysis and interpretation;

D - writing the article; $\mathbf{E}$ - critical revision of the article; $\mathbf{F}$ - final approval of the article

\begin{abstract}
Osteomyelitis in patients undergoing surgery because of injuries and diseases of the musculoskeletal system is a serious clinical, economic and social problem. It is one of the greatest therapeutic challenges in traumatology and orthopedic surgery. To achieve the best results in the treatment of osteomyelitis, surgical debridement and intravenous antibiotic therapy is supported by local antibiotic delivery. Many different substances can be used as drug carriers. In this study we present and compare some polymers used as carriers of gentamicin. Some of them, such as poly(methyl methacrylate), are well known and have been used for 30 years, and others, such as polycaprolactone, polyacrylic acid, polyanhydrides, poly-trimethylene carbonate, polylactide, polyglycolide and poly(trimethylene carbonate), are perspectives for the future. In this study, we have tried to briefly present all of these polymers and compare some of their features. We have concentrated on the pharmacokinetics and bioactivity of such implants, which are important aspects for their potential practical use (Polim. Med. 2016, 46, 1, 101-104).
\end{abstract}

Key words: polymers, gentamicin, osteomyelitis, drug carriers.

Bacterial infections are a serious problem in musculoskeletal system surgery [1-3]. The complication rate is significantly higher in patients undergoing surgery because of acute injuries than in scheduled surgery [4]. In traumatology, the highest rate of infection is in patients with open fractures [5], and in orthopedic surgery in patients with implants such as an endoprosthesis [6]. In both cases, the problem is due to the antibiotic's poor penetration into the operation site [7-10]. The kind of bacterial strains that we deal with also play a significant role in osteomyelitis. Very often these are strains resistant to the most commonly available antibiotics such as methicillin-resistant Staphylococcus aureus (MRSA), Enterobacter, Pseudomonas or Streptococcus ssp. [11]. Treatment of osteomyelitis depends on its clinical grade, which is estimated with the use of certain classifications, such as those created by Cierny and Mader or by Lew and Waldvogel [12-14]. Surgical debridement and blood supply restoration associated with general and local antibiotic therapy seem to be the best course in the treatment of osteomyelitis [15-17]. A lot of substances are used as drug carriers in local antibiotic ther- apy, but not all antibiotics may be used to create such medicines. The main problem is the antibiotic's activity after combination with such carriers [18]. Gentamicin is one of the most commonly used antibiotics in local treatment because of its thermal stability and resistance to the sterilization process. In clinical practice, an implant made of poly(methyl methacrylate) (PMMA) and gentamicin has been in use for over 30 years $[19,20]$. It is well known in Europe as a commercial product such as Septopal ${ }^{\mathrm{TM}}$ [21] (Fig. 1). PMMA is a biocompatible but not bioabsorbable biomaterial. The positive results obtained in osteomyelitis treatment using PMMA beads with gentamicin application have inspired studies on new kinds of polymeric drug carriers such as polycaprolactone (PCL) [23], polyacrylic acid [24], polyanhydrides [25], poly-trimethylene carbonate [26], polylactide (PLA) [27], polyglycolide (PGA) [28] and poly(trimethylene carbonate) (PTMC) [26]. Their main common feature in contrast to PMMA is their biodegradation. PMMA beads need to be removed during a secondary surgery [22], which is their main disadvantage. PMMA, as a non-absorbable polymer, can also be 


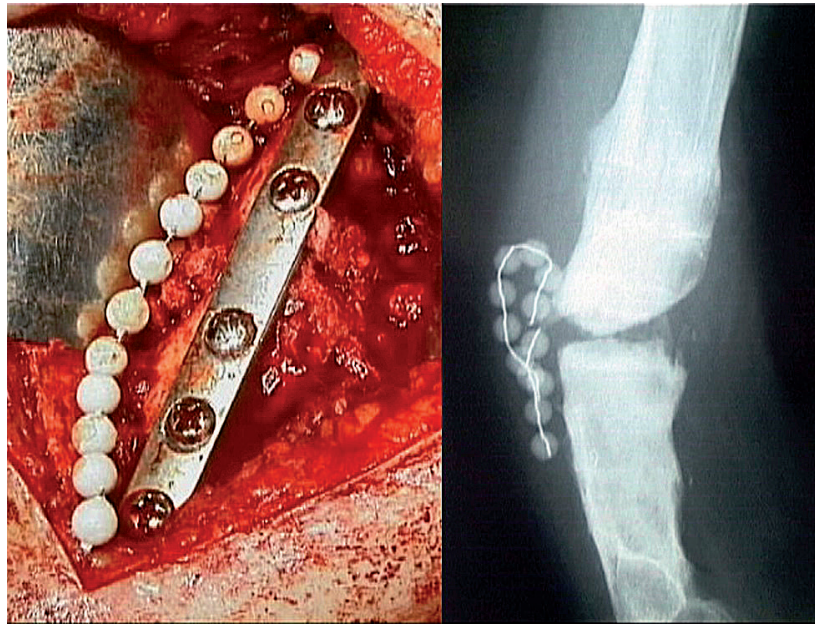

Fig. 1. Clinical examples of PMMA bead usage in osteomyelitis treatment in own material

\section{Conclusions}

The aim of this study was to present the polymeric materials used as a gentamicin carriers for local treatment in osteomyelitis. We also wanted to compare some of their pharmacokinetic features and bioactivity, which are important for potential clinical use. One problem was that we do not have enough data available in a few cases because a lot of the published studies have an introductory character and a lot of others have only been done on in vitro models. There is no possibility of a proper comparison in the case of data achieved on in vivo and in vitro models. Some side effects, such as the increased fibrotic tissue creation or decreased bone regeneration described in PGA, PLA and PCL use or the risk of secondary biofilm creation on PMMA beads, are generally known and proven in multiple stud-

Table 1. Comparison of pharmacokinetic features and bioactivity of polymeric implants with gentamicin

\begin{tabular}{|c|c|c|c|c|c|}
\hline Name of substance & $\begin{array}{l}\text { Biodegradation } \\
\text { ability }\end{array}$ & $\begin{array}{l}\text { Time of biodegrada- } \\
\text { tion (in months) or } \\
\text { necessity of removal }\end{array}$ & $\begin{array}{l}\text { Time of gentamicin } \\
\text { release (in weeks) }\end{array}$ & $\begin{array}{l}\text { Amount of gentami- } \\
\text { cin released }\end{array}$ & Side effects \\
\hline $\begin{array}{l}\text { PMMA (poly(methyl } \\
\text { methacrylate)) }\end{array}$ & no & $\begin{array}{l}\text { needs to be remo- } \\
\text { ved }\end{array}$ & up to16 [29] & $20-70 \%$ & $\begin{array}{l}\text { secondary bacterial } \\
\text { biofilm creation }\end{array}$ \\
\hline $\begin{array}{l}\text { PCL (polycaprolac- } \\
\text { tone) }\end{array}$ & yes & up to $30[30]$ & up to 2 & up to $80 \%[31]$ & $\begin{array}{l}\text { uncontrolled growth } \\
\text { of fibrotic tissue }\end{array}$ \\
\hline Polyacrylic acid & yes & $\begin{array}{l}\text { no in vivo tests ava- } \\
\text { ilable }\end{array}$ & no information & up to $100 \%$ & no serious side effects \\
\hline Polyanhydrides & yes & $\begin{array}{l}\text { up to a few (depen- } \\
\text { ding on the type } \\
\text { and ratio of the mo- } \\
\text { nomers) }\end{array}$ & up to 4 & up to $100 \%$ & no side effects \\
\hline PLA (polylactide) & yes & $72-84[32]$ & up to 1.5 & up to $100 \%$ & $\begin{array}{l}\text { acidic degradation } \\
\text { products and a subse- } \\
\text { quent decrease in local } \\
\text { pH are the cause of } \\
\text { decreased bone rege- } \\
\text { neration [33] }\end{array}$ \\
\hline PGA (polyglycolide) & yes & $12[34]$ & up to 1.5 & up to $100 \%$ & $\begin{array}{l}\text { acidic degradation } \\
\text { products and a subse- } \\
\text { quent decrease in local } \\
\text { pH are the cause of } \\
\text { decreased bone rege- } \\
\text { neration [33] }\end{array}$ \\
\hline $\begin{array}{l}\text { PTMC (poly-trime- } \\
\text { thylene carbonate) }\end{array}$ & yes & 2 & up to 2 & up to $60 \%[26]$ & no side effects \\
\hline
\end{tabular}

a localization for secondary bacterial biofilm creation after gentamicin release. Although the new, bioabsorbable materials seem to be better than PMMA because of the lack of necessity to remove them after their implantation, they have some serious disadvantages in comparison to PMMA beads.

In the Table 1 above, some of the main features of these polymers are presented. ies. We found a lot of data about the rest of the polymers, i.e. PTMC, polyacrylic or polyanhydrides, but we don't know much about the potential side effects after implantation of such products as gentamicin carriers in a human body. All these polymers were described only as a potential carriers of gentamicin and, in many studies, a comparison with non-absorbable PMMA beads only had an experimental character. In the current state of knowledge, we can say that PMMA beads with genta- 
micin are the only polymer carrier which is widely used in clinical practice and has a well-documented antibacterial effect. The potential use of absorbable polymers as a gentamicin carrier in the treatment of osteomyelitis necessitates many specific tests including in vivo experiments on animal models. At present, they are one of the potential prospects in local antibiotic therapy development in the future.

Acknowledgment. The authors would like to thank Bartosz Witkowski for his writing and editing services.

\section{References}

[1] Oliveira P.R., Carvalho V.C., da Silva Felix C., de Paula A.P., Santos-Silva J., Lima A.L.: The incidence and microbiological profile of surgical site infections following internal fixation of closed and open fractures. Rev. Bras. Ortop. 2016, 51, 396-399. DOI: $10.1016 /$ j.rboe.2015.09.012.

[2] Parkkinen M., Madanat R., Lindahl J., Mäkinen T.J.: Risk factors for deep infection following plate fixation of proximal tibial fractures. J. Bone Joint Surg. Am. 2016, 98, 1292-1297. DOI: 10.2106/JBJS.15.00894.

[3] Manian F.A., Kelly E.: Lower extremity acute bacterial skin and soft tissue infection following total knee arthroplasty. Am. J. Med. Sci. 2016, 352, 154-158. DOI: 10.1016/j.amjms.2016.05.004.

[4] Barbero J.M., Montero E., Vallés A., Plasencia M.A., Romanyk J., Gómez J.: Prosthetic joint infection in patients with hip fracture. Differences from infection of elective prosthesis. Rev. Esp. Quimioter. 2016. pii: barbero28jul2016 [Ahead of print].

[5] Gustilo R.B., Anderson J.T.: Prevention of infection in the treatment of one thousand and twenty-five open fractures of long bones: Retrospective and prospective analyses. J. Bone Joint Surg. Am. 1976, 58, 453-458.

[6] Landor I., Vavrík P., Jahoda D.: General principles of infection treatment in joint replacements. Acta Chir. Orthop. Traumatol. Cech. 2005, 72, 183-190.

[7] Landersdorfer C.B., Bulitta J.B., Kinzig M., Holzgrabe U., Sörgel F.: Penetration of antibacterials into bone: pharmacokinetic, pharmacodynamic and bioanalytical considerations. Clin. Pharmacokinet. 2009, 48, 89-124. DOI: 10.2165/0003088200948020-00002.

[8] Traunmuller F., Schintler M.V., Metzler J. et al.: Soft tissue and bone penetration abilities of daptomycin in diabetic patients with bacterial foot infections. J. Antimicrob. Chemother. 2010, 65, 1252-1257. DOI: 10.1093/jac/dkq109.

[9] Garazzino S., Aprato A., Baietto L. et al.: Glycopeptide bone penetration in patients with septic pseudoarthrosis of the tibia. Clin. Pharmacokinet. 2008, 47, 793-805. DOI: 10.2165/0003088-200847120-00004.

[10] von Baum H., Böttcher S., Abel R., Gerner H.J., Sonntag H.G.: Tissue and serum concentrations of levofloxacin in orthopaedic patients. Int. J. Antimicrob. Agents 2001, 18, 335-340.

[11] Lew D.P., Waldvogel F.A.: Osteomyelitis. N. Engl. J. Med. 1997, 336, 999-1007.

[12] Lew D.P., Waldvogel F.A.: Osteomyelitis. Lancet 2004, 364, 369-379.

[13] Cierny G. 3rd, Mader J.T., Penninck J.J.: A clinical staging system for adult osteomyelitis. Clin. Orthop. Relat. Res. 2003, $414,7-24$.

[14] Mader J.T., Shirtliff M., Calhoun J.H.: Staging and staging application in osteomyelitis. Clin. Infect. Dis. 1997, 25, 1303-1309.

[15] Walter G., Kemmerer M., Kappler C., Hoffmann R.: Treatment algorithms for chronic osteomyelitis. Dtsch. Arztebl. Int. 2012, 109, 257-264. DOI: 10.3238/arztebl.2012.0257.

[16] Calhoun J.H., Manring M.M.: Adult osteomyelitis. Infect. Dis. Clin. North Am. 2005, 19, 765-786.

[17] Cancienne J.M., Burrus M.T., Weiss D.B., Yarboro S.R.: Applications of local antibiotics in orthopedic trauma. Orthop. Clin. North Am. 2015, 46, 495-510. DOI: 10.1016/j.ocl.2015.06.010.

[18] Lalidou F., Kolios G., Drosos G.I.: Bone infections and bone graft substitutes for local antibiotic therapy. Surg. Technol. Int. 2014, 24, 353-362.

[19] Seligson D., Berling S.: Antibiotic-laden PMMA bead chains for the prevention of infection in compound fractures: current state of the art. Eur. J. Orthop. Surg. Traumatol. 2015, 25, 969-974. DOI: 10.1007/s00590-015-1652-z.

[20] Klemm K.: The use of antibiotic-containing bead chains in the treatment of chronic bone infections. Clin. Microbiol. Infect. 2001, 7, 28-31.

[21] Zimmer K.: Use of mini-septopal in trauma surgery of the hand. Experimental and clinical studies. Polim. Med. 1996, $26,3-57$.

[22] Zalavras C.G., Patzakis M.J., Holtom P.: Local antibiotic therapy in the treatment of open fractures and osteomyelitis. Clin. Orthop. Relat. Res. 2004, 427, 86-93.

[23] Teo E.Y., Ong S.Y., Chong M.S. et al: Polycaprolactone-based fused deposition modeled mesh for delivery of antibacterial agents to infected wounds. Biomaterials 2011, 32, 279-287. DOI: 10.1016/j.biomaterials.2010.08.089.

[24] Changez M., Koul V., Dinda A.K.: Efficacy of antibiotics-loaded interpenetrating network (IPNs) hydrogel based on poly(acrylic acid) and gelatin for treatment of experimental osteomyelitis: in vivo study. Biomaterials 2005, 26, 2095-2104.

[25] Laurencin C.T., Gerhart T., Witschger P. et al: Bioerodible polyanhydrides for antibiotic drug delivery: in vivo osteomyelitis treatment in a rat model system. J. Orthop. Res. 1993, 11, 256-262.

[26] Neut D., Kluin O.S., Crielaard B.J., van der Mei H.C., Busscher H.J., Grijpma D.W.: A biodegradable antibiotic delivery system based on poly-(trimethylene carbonate) for the treatment of osteomyelitis. Acta Orthop. 2009, 80, 514-519. DOI: 10.3109/17453670903350040.

[27] Morawska-Chochół A., Domalik-Pyzik P., Chłopek J. et al.: Gentamicin release from biodegradable poly-1-lactide based composites for novel intramedullary nails. Mater Sci. Eng. C Mater. Biol. Appl. 2014, 45, 15-20. DOI: 10.1016/j. msec.2014.08.059. 
[28] Dorati R., DeTrizio A., Genta I. et al.: An experimental design approach to the preparation of pegylated polylactide-co-glicolide gentamicin loaded microparticles for local antibiotic delivery. Mater. Sci. Eng. C Mater. Biol. Appl. 2016, 58, 909-917. DOI: 10.1016/j.msec.2015.09.053.

[29] Wahlig H., Dingeldein E., Bergmann R., Reuss K.: Experimental and pharmacokinetic studies with gentamicin PMMA beads. Zentralbl. Chir. 1979, 104, 923-933.

[30] Sun H., Mei L., Song C., Cui X., Wang P.: The in vivo degradation, absorption and excretion of PCL-based implant. Biomaterials 2006, 27, 1735-1740.

[31] Chang H.I., Lau Y.C., Yan C., Coombes A.G.: Controlled release of an antibiotic, gentamicin sulphate, from gravity spun polycaprolactone fibers. J. Biomed. Mater. Res. A 2008, 84, 230-237.

[32] Bergsma J.E., de Bruijn W.C., Rozema F.R., Bos R.R., Boering G.: Late degradation tissue response to poly(L-lactide) bone plates and screws. Biomaterials 1995, 16, 25-31.

[33] Gunatillake P.A., Adhikari R.: Biodegradable synthetic polymers for tissue engineering. Eur. Cell Mater. 2003 , 5, 1-16.

[34] Pihlajamäki H.K., Salminen S.T., Tynninen O., Böstman O.M., Laitinen O.: Tissue restoration after implantation of polyglycolide, polydioxanone, polylevolactide, and metallic pins in cortical bone: An experimental study in rabbits. Calcif. Tissue Int. 2010, 87, 90-98. DOI: 10.1007/s00223-010-9374-z.

\author{
Address for correspondence: \\ Jarosław Witkowski \\ Borowska 213 \\ 50-556 Wrocław \\ Poland \\ E-mail: witwitwit@wp.pl \\ tel.: +48608501378 \\ Conflict of interest: None declared
}

Received: 18.08.2016

Revised: 23.08.2016

Accepted: 7.09.2016 